\title{
Evaluation on The Application of The Accrued Fixed Assets in The East Java Local Government
}

\author{
Lilik Pirmaningsih \\ Departemen Akuntansi Fakultas Ekonomi \\ Universitas Wijaya Kusuma Surabaya \\ Surabaya, Indonesia \\ lilik_pirma@yahoo.co.id
}

\author{
Lilik Mardiana \\ Departemen Akuntansi, FakultasEkonomi \\ Universitas Wijaya Kusuma Surabaya \\ Surabaya, Indonesia \\ lilikmardiana@ymail.com
}

\author{
Noor Tri Hastuti \\ Departmen Hukum, FakultasHukum \\ Universitas Wijaya Kusuma Surabaya \\ Surabaya, Indonesia \\ noortrihastuti@yahoo.com
}

\begin{abstract}
Fixed asset having of considerable value in local government financial position. The accrued system is treatment accounting to the fixed assets according to the standard of government accounting, that reflects the condition of being indeed. Research objectives identify constraints that have been faced the regional government and the policy taken in applying the system akrual on fixed asset. The research is the process to realize government good corporate governance which have resulted in a report local financial reliable and accountable. This research is descriptive qualitative, data is collected through observation, interviews and documentation. Object research is the local government Sidoarjo, Gresik, Mojokerto, and Malang. The results of the study all local governments have applied system the accrued on fixed assets regional since 2015 , and has set policy regulations accounting through government regulation. In the financial position has reported accumulated depreciation, and the burden on their depreciation operational on the report. As for constraints that have been faced is the device regulations accounting based the accrued incomplete, the process of drafting the and development application regional financial not based on analysis needs, and to limited human resources related.
\end{abstract}

Keywords-regional the fixed assets; accrual system; and government accounting standards

\section{INTRODUCTION}

In line with government, good corporate governance and demands financial report the government should reliable. These claims are more pressure on the government to be responsible on how use public money in the management of the government. The accrual basis is considered to be better able to provide information financial statements compared with the base cash. Contributing to public sector reform , make government should not to use only financial statements in the context of cash but also on the use of informations provided by financial statements as a basis for decision making.
Conceptually accounting based the accrued can produce more information and accountable transparent compared with accounting based cash. In addition the accrual basis is also capable of supporting the implementation of the calculation of the cost of a wide range of public services provided by the Government with reasonable. Recording and all the calculation, both have paid and an unpaid in a base the accrued make accounting the accrued based conceptually can provide measurements better, timely recognition, and disclosure liabilities in the future. If seen in order performance assessment, the accrued based information can provide information on the use of economic resources the truth.

The PP No. 712010 as government accounting system based the accrued have the law, and the government obligation to apply standard to based the accrued. The purpose of this research was to identify constraints facing local government and its policy is to apply the accrual system on the fixed assets area.

\section{LITERATURE REVIEW}

Local government financial report according to the standard government accounting.

Accounting is the identification process, recording, the measurement of classification of financial transactions and the chain, presentation of report, and interpreted over the results. Government accounting standards are the principles of accountancy applied in preparing and presenting government financial report. Government accounting based the accrued is record accounting acknowledging income, expense, assets , debt, and equity in financial reporting based the accrued, and acknowledging income, expenditure, and funding of the in reporting budget implementation based on the state budget/local budget. Government accounting standards based cash to the accrued is standard government accounting 
acknowledging income, spending, and funding cash based, and admitted assets, debt, and equity funds the accrued based. The government accounting standards based the accrued can be implemented in stages of the application of government accounting standards based to the accrued cash into the government accounting standard based the accrued.

Basic financial report consist of: realization budget report, reports change the balance of the budget more, the balance of, operational reports, cash flow reports, reports the equity changes, and the record on the financial report. Besides financial report a staple over, entity reporting must presenting other reports and / or elements information accounting required by the provisions of the legislation.

The base accounting used in government financial report is a base the accrued, for recognition income, expense, assets , liabilities, and equity. Operational Reports for accrual basis means that revenue is recognized at the time the right to earn income have been met even though cash have not been provided, and expense recognized when liability reduced the value of the net worth of cash has accomplished although they had not been issued. Income as outside help in the form of services in a report presented also operational.

\section{Accrual System For Fixed Assets}

Understanding assets or goods belonging to a region in the ministerial decision domestic and finance minister decision that all goods bought or that obtained upon the local budget or derived of its other legal. Assets are recorded in the amount of spending cash and cash equivalents paid or the fair value of the reward of (consideration) to acquire the assets at the time of acquisition. Assets at the time recognized the potential economic benefits the future obtained by the government and is worth or cost can be measured with reliable. In line with the application of the base the accrued, assets in the form of a receivable or expenses paid in advance recognized when the right claims to get cash flow in or other economic benefits from another entity has been or still fulfilled, and value of the claims can be measured or estimated.

The fixed assets classified based on similarity in nature or their function in the activity of operating entities. Classifications fixed asset is as follows: (a) land; ( b ) of equipment and engines; ( c ) buildings; ( d ) road, irrigation , and tissues; ( e ) other fixed assets; and ( f ) construction work in progress.

Fixed asset recognized at the time of economic benefits the future can be obtained and value can be measured with a reliable. To be recognized as fixed asset should be filled the following criteria: (a) tangible ; (b) have the benefits of more than 12 ( twelve months; ) (c) the cost of its assets can be measured in reliable and; (d) not be sold in normal operations entity; and (e) obtained or built with a view to be used.

Fixed asset be measured by the cost. When asset valuation still using the cost of its not allowing and asset value continue to be based on the reasonable value at the time of its. Measurements can be considered reliable exchange in transactions when there is evidence of purchase can be used to identify the cost is the fixed assets. In the condition of a assets that are constructed, a measurement of that can be relied if cost can be obtained from the transaction external sides with the entity so far the result of raw materials, labor and other costs that used in the process of construction.

\section{RESEARCH METHODS}

\section{Research Approach}

The research is descriptive qualitative research that gives descriptions of the problems faced by regional governments in order to apply the system accrual on fixed asset in accordance with the government accounting standards. Application of the system the accrued of a series of further than the local government in an effort to create government good corporate governance so that financial report government can trust public. An object research, the regional governments Sidoarjo , Gresik, Malang and Mojokerto

\section{Data and Analysis}

Data collections done is to determine the design of research that is worn: (1) Observation done to look constraints that have been faced local governments in implemented the system accrual on fixed asset of the aspect of human resources , of facilities and infrastructure and regional policy about the system accrual on a fixed asset. (2) Interview done to seek data about human resources and how regional policy about the system accrual on fixed asset run.

Consistent with the objectives to be achieved by researchers, hence this research will be done in stages, includes: (1) Evaluation application of the system the accrued fixed asset regions. At this stage directed for monitoring and identification carefully aspects human resources, facilities and infrastructure owned by regional government for implementing the system the accrued fixed asset region in standard government accounting. (2) Analysis of data; the data have been collected in the first phase next do the processing of data and an analysis in order to get similarities and differences between each local government Sidoarjo, Gresik, Malang, and Mojokerto. (3) The data that has been mixed and analyzed tabulation for each regional government that can be drawn the red about constraints in application of the system the accrued on assets fixed regions and incorporated be a result research report.

\section{RESULT AND DISCUSSIONS}

\section{A. Contraints faced by local governments in order to new} system the accrued on fixed assets will be in accordance with government accounting standards.

Local Government Sidoarjo.

In general the results of an examination into financial reports and interviews with related authors the formulation process financial statements consolidation it is known that process of the financial statements the district government Sidoarjo inadequate with a description as follow:

a. Management inventories of division in working units not orderly; (1) there are building private schools 
that have not granted, so that still listed supplies in Education Department. (2) there are equipment which do not do recording.

b. Market buildings Krian and Wadungasri worth Rp 2.472.500.000,00 who demolished based cooperation partnership agreement not yet abolished from government assets Sidoarjo. This condition not according to PP No 712010.

c. A device regulations and accounting the accrued application based in the district government of sidoarjo not fully adequate, namely; (1) A device accounting regulations based the accrued the government Sidoarjo not yet complete (2) The process of drafting the and development application regional financial not based on analysis needs.

\section{Gresik Government}

The results of an investigation into the supporting documents presentation of the fixed assets in the balanced shows that manage to fixed asset or goods belonging to a region still not orderly, the asset management less than optimal in implementing the tasks and functions management, the inventory card insufficient and security still not orderly assets, with a description as follows;

a. The management of assets not fully duty and function. In implementation of management fixed assets, Asset management division only to carries on the function of collection and compilation data inventory card, while for the content of the data disseminated has not been done analysis and the assessment on conformity information the fixed assets have input on their card inventory.

b. Cards of inventory are inadequate management. The results of the examination on card inventory in 31 December 2015 indicating the existence of problems following ; (1) There are the results of maintenance fixed assets not capitalized or noted separate of the fixed assets original. (2) Planning costs, controlling, and cost that attribution not yet capitalization. (3) There are fixed asset recorded double on three SKPD. (4) there are fixed assets that have been removed but still listed on the cards inventories. (5) Recording fixed asset does not include the year. (6) There are still recording asset value in accumulated. (7) There are some record fixed assets unreasonable. (8) The fixed assets in a general election commission recorded in its own inventory card and not to be in responsibility division. (9) Recording the receipt of grants and Assets of the Corporate Social Responsibility (CSR). (10) There are equipment and buildings with the condition of the heavily damaged proposal the removal of has not been carried out.

c. Security and maintenance of the fixed assets disorderly. Based on examination on the fixed assets owned by the district government Gresik that are presented in the balanced as per December 312015 known the following; (1) there are land which controlled by other parties. (2) Determination of the location of the land build a health villagers Sembungan Kidul exceed if land got pledged. (3) There are lost document has not been carried out the process of reporting lost.
Local Government Malang.

In general the constraints in the application of fixed asset based the accrued is as follows;

1. Accounting policy that is not managed calculation the attribution on fixed asset to holding assets, so that one assets can record into several assets to correspond cost of a year; and the addition of economic the benefits assets fixed with respect to capital expenditure who motionlessness attributable to fixed asset holding.

2. Lack of or not found documents or the early evidence acquisitions

3. Difficulties in counting returned toward fixed assets.

Local Government Mojokerto.

The obstacles in the application of fixed asset based on the accrued: is as follows ;

1. Management, Administration, and presentation of fixed assets not yet fully adequate.

2. Technical instructions depreciation fixed asset conflict with the accounting policies of local governments.

3. The inventory card of Education Department orderly not all

4. Do not have the technical set of coordination between the goods until to the assets.

Local government policies issued in order to apply the accrual system on fixed assets Government Accounting Standards.

Each local government issued a regulation but those policies accrual basis set in generally about the application of accrual basis. Example, Regulation of Sidoarjo Regent No.60 Th. 2015 about the first change over Regulation Sidoarjo Regent No. 49 Th. 2014 about Accounting Policies and Regulations 49 of Sidoarjo Regent Th. 2015 about Accounting Systems of Local Government District Sidoarjo. There has been no government policy that specifically set up for the fixed asset accrual base area, resulting in operational if getting the constraints of each local government will take decisions by way of the local government of origin point of view does not deviate from the Government Accounting Standards.

\section{CONCLUSION}

In general the constraints facing local governments in order to apply the accrual system on fixed assets in accordance with government accounting standards is a regulatory accounting accrual-based device that is not yet complete, the process of drafting and development finance application area is not based on an analysis of needs, and human resource limitations. The local government policies issued in order to apply the accrual system on fixed assets government accounting standards, already made by the respective local governments through regulation of the Governors, but not yet covered all accounting policies accrual-based. 
Each local government need to drawing up a regulation changes to accommodate the lack of implementation of accrual-based accounting policies that are adapted to the conditions of the respective local governments. Therefore, they need to improve or draw up development application local financial adjusted to the needs of each local government. Upgrading or expertise human resources to does the work of related.

\section{REFERENCES}

[1] Ara Adventana, Gabriella, Ch. Heni Kurniawan, "Anylisis of Factorfactor that affecting the provincial government DIY in implementing accrued according to Government Regulation No 71 2010",Faculty Economy, University of Atma Jaya Yogyakarta.

[2] Christy Soputan, Julie J. Sondakh, Steven Tangkuman, "Presentation of Government Financial Statement based on PP No. 7 2010, about Government Accounting Standard in North Sulawesi”, Faculty Economy and Bussiness of Accounting in journal EMBA vol. 3 No. 1 Maret 2015, pp. 592-600.

[3] Departemen Dalam Negeri dan Lembaga Administrasi Negara, "Basics of Manajement Assets", Training Technical Local Asset Management, Jakarta, 2007

[4] DoliSiregar, "Optimization empowerment wealth the state", Gramedia Pustaka Utama, 2002

[5] Halim Abdul, Muhammad SyamKusufi, "Akuntansi Sektor Publik :Akuntansi Keuangan Daerah (SAP BerbasisAkrual)",Edisi 4, Penerbit Salemba Empat.

[6] Jan Hoesada-Anggota KSAP, "Twenty-five reason depreciation the fixed asset in government accounting." diakses dari http://www.docs.google,

[7] Kema, Ihwal. 2003. "Presentation of regional financial report based on standards government accounting the city government Manado", Univercity of Sam Ratulangi Manado, Journal EMBA vol. 1 No. 3, 2013 pp. 771-781

[8] Mahmudi, "An analysis of local government financial report “, thrid edition, UPP STIM YKPN, Yogjakarta.

[9] Mahmudi, "Financial Management Areas “,Erlangga, Jakarta, 2002

[10] Plenary paper I, "Accrual Based Financial Reporting" Government Accounting Standards Committee.

[11] Mardiasmo, "Public Sector Accounting", Andi, 2009.

[12] Autonomy and Regional Financial Management, AndiPubliser.
[13] Margono, Widyaiswara Madya State Education Training Center for Wealth and Financial Balance, "Accounting Based on Accrual for The Regional Device Work Unit,"Financial and Training Agency of Finance Ministry.

[14] MashudiArif, Moh, Hendrawan Santosa Putra, Taufik Kurrohman, "Analysis of Local Government Readiness in Implementation of Accrual Based Government Acconting Standard (Study at Local Government of Bondowoso Regency)," Faculty Economy, Univercity of Jember.

[15] Noor tri Hastuti, "Arrangements regarding Law Enforcement in the Management of Regional Property," Research Report For Dissertation, 2013.

[16] NurAiniRahayu, Herman Karamoy, Winston Ponton, "Application of Accounting Information System of State Property at High Court of Manado Religion," Faculty Economy and Bussiness of Accounting, Univercity of Sam Ratulangi Manado, Journal EMBA vol. 2 no.1 Maret 2014, pp 11-20.

[17] Oktavia Ester Pangaribuan, Sumini Widyaiswara Muda, "Module of Fundamentals of Management of Regional Property," Pusdiklat the wealth of the country and financial balance the state

[18] Indonesia Government, "Minister for Finance No. 238/PMK.05/2011 about The General Guidelines Government Accounting System.

[19] Ministerial Regulation No. 172007 "Tecnical Guidelines Management Regional Belongings."

[20] Indobesia Government, UU No 17/2003, "State Finance".

[21] Indonesia Government, "PP No. $71 / 2010$ Government Accounting Standard, State gazette of the Republic of Indonesia 2010 No.123

[22] Indonesia Government, Presidential regulation no. 54 / 2010 about procurement of goods and services the government.

[23] Indonesia Government, "PP No.2/2001 Security and the transfer of goods belonging to the wealth of the country /from the central government to the regions within the framework the implementation of regional autonomy," State gazette of the Republic of Indonesia No.6/2001.

[24] Soekarwo, "The regional financial management based on prinsipprinsip good financial governance,"Airlangga University Press, Surabaya, 2005

[25] Tri Hastuti, Noor, "Arrangement on law enforcement in the management of goods belonging to a region,"UWKS, 2014.

[26] Tri Hastuti, Noor, LilikMardiana, LilikPirmaningsih, "The concept of management section belongings based on the system of the accrued in preventing corruption; studies in kabupaten / city East Java ," UWKS.

[27] Tuanakotta M Theodurus, "Forensic Accounting and Auditing Investigative,” Publisher FE UI, 2007. 